\title{
ENERGY SAVING AND EFFICIENCY PROPOSALS FOR SUSTAINABLE TOURISM DEVELOPMENT AND CONTINUATION: TURKEY EXAMPLE
}

\author{
Azim Doğuş TUNCER ${ }^{57}$ \\ Mustafa AKTAŞ ${ }^{58}$
}

\begin{abstract}
The concept of sustainability emerging within the environmental movement is closely related to the tourism sector as well as to many sectors. In this study, suggestions are given to reduce harmful emissions in Turkey, especially by facilities based on mass tourism. In addition, renewable energy-based energy performance enhancing technologies that can be applied to the energy efficiency and efficiency of tourism facilities are also proposed to reduce carbon footprint. Considering the incentives and discounts applied by the Ministry of Culture and Tourism of the Republic of Turkey for "environmentally sensitive accommodation facilities", the advantages and advantages of Photovoltaic Thermal (PV-T) Collector Technology which is suitable for use of the facilities are introduced and the advantages of these technologies are discussed. As a result of the cost analysis, the system which will be applied at a sample tourism facility is amortizing itself in 3.5 years.
\end{abstract}

Key words: Sustainable tourism, energy efficiency, renewable energy, photovoltaic thermal collectors

\footnotetext{
${ }^{57}$ Research Assistant, Mehmet Akif Ersoy University, Faculty of Engineering and Architecture, Energy Systems Engineering, Burdur, Turkey, e-mail: atuncer@mehmetakif.edu.tr

${ }^{58}$ Professor, Department of Energy Systems Engineering, Faculty of Technology, Gazi University, Ankara, Turkey, e-mail: mustafaaktas@gazi.edu.tr
} 


\section{INTRODUCTION}

The general outline of sustainable development, a concept emerging within the environmental movement, was defined in the Brundtland Report published in 1987 and was described as "meeting today's requirements without sacrificing the ability of future generations to meet their needs" [1].

The environmental aspect of the concept of sustainable development is related to the natural environment of human activities. People are able to find all the resources they need in a natural environment, provide energy from natural ecological systems to convert the material into economic goods, while at the same time helping to absorb the wastes generated during this conversion process. Unconsciously consuming our natural resources, trees from renewable natural sources used before being rebuilt, water creatures; in short, all the wildlife is negatively affected, and many minerals consumed more rapidly than the rate of reproduction naturally are destroyed. From here it should not be overlooked that limiting the use of nonrenewable resources, limiting the consumption of renewable resources or requiring careful use [2]. Successful progress of environmental sustainability is possible through ecological diversity and the preservation of sustainable resources.

The most significant reduction in people's impact on the ecosystem is another important point in terms of environmental sustainability. Minimization of human impacts is necessary and important in terms of ecosystem sustainability and biodiversity. Protecting ecosystem health and protecting species threatened by extinction, avoiding consumption of renewable resources at more than the rate of regeneration, avoiding the use of renewable sources (fossil fuels and minerals) at a higher rate than displacing renewable ones, natural absorption of pollution and garbage; so that the harmful effects can not be removed more quickly than if they were removed and re-enriched, and that the per capita resource utilization is within the bounds of carrying capacity [3]. Goodland has defined environmental sustainability as "sustaining natural capital" and stated that sustainability should include the following three rules [4]:

1. Output rule: Emissions originating from the project or activity must be kept within the confines of the acidic capacity without reducing the waste absorption capacity in the future, and without any deterioration of its lucrative benefits.

2. Input rule: The consumption rate of renewable resources must be kept within the capacity of the natural system to regenerate resources.

3. Operational Principles:

a. Renewable resources must be used in sustainable efficiency, in a way that optimizes utility and within fully sustainable rules.

b. The technological development of sustainable development should be energy and material enhancing, not enhancing. 
c. If the scale of the human economic subsystem, the technology used per unit of population, is not optimal, transport capacities should be kept at least sustainable.

It is impossible to think independently of the tourism sector. Sustainability and tourism can be said to be the whole of the environment, sustainability and tourism when it is thought that the region can benefit from the natural resources of the region to live its life in the region visited by tourists moving between the regions or if it can give up the desire to travel with the destruction of any natural source which is a tourist attraction. The fact that the tourism sector can operate in a balanced and continuous manner depends on the existence of natural and cultural resources. Goods and services produced by tourism enterprises are formed around natural and cultural resources.

The World Tourism Organization (WTO) defines sustainable tourism as: Sustainable Development in Tourism; adopts the principle of meeting the needs of today's tourists and the hosts who are hosting them, protecting and developing future opportunities. Management of all resources in this way; cultural integrity, compulsory ecological processes, biological diversity and life support systems are to be sustained while economic, social and aesthetic requirements are met. Sustainable tourism products; products that are handled in harmony with the local environment, society and cultures that are useful instead of being damaged by tourist development.

According to the World Bank estimates, around 6.8 billion people live in the world in 2010 and this figure is expected to reach about 8 billion by 2025 . This means that about $93 \%$ of the population growth will be due to the population increase in low and middle-income countries[5]. Again according to the same data, the population living in cities in 2030 will reach twice the rural population. The key to sustainable tourism sustainable development can be considered in two dimensions: the contribution of the tourism sector to the sustainable development through the structure of developing countries and the adverse effects on the ordinary traveling tourism sector.

International tourism grew about four times in the past 30 years, during which time local tourism has increased intensively, especially in developing countries. These developments have made the tourism industry one of the important economic sectors that generate foreign exchange and create income and employment [6].

Tourism has some environmental consequences of its development on a global basis at high speed. For example, in the world scale, tourism accounts for about $5 \%$ of greenhouse gas emissions, but it is estimated that by 2035 this ratio will increase by $130 \%$ [7]. It is thought that it is already affected by climate change and will change the course of tourism, which has undergone geographical changes at this scale. In this respect, the United Nations called on the sector to adopt "sustainable tourism" practices and this call responded to both to reduce environmental impacts, to ensure 
efficient use of resources, and to ensure the social and economic sustainability of regions and companies.

Sustainable tourism does not mean to control the sector or to manage the adverse effects of tourism. Tourism has a very special place in terms of providing economic and social benefits to the local people and protecting the environment. Economic development and environmental protection in tourism should not be considered as contradictory goals. With the right policies, these two facts will strengthen each other. However, policies and actions should be shaped to increase the benefits of the tourism sector and reduce costs.

\section{INCENTIVES AND REGULATIONS IN THE TOURISM SECTOR IN TURKEY ON BEHALF OF ENVIRONMENTAL AWARENESS AND SUSTAINABLE ENERGY USE}

Within the scope of sustainable tourism, "Environment Friendly Establishment Certificate" is given by the Ministry of Culture and Tourism of Republic of Turkey to accommodation facilities which have demanded and sought after qualities since 1993 in order to protect the environment, develop environmental awareness, encourage the positive contribution of tourist facilities to the environment. "Communiqué no 2008/3 on the Issuance of Accommodation Facility Responsible for Tourism Facilities Certified Accommodation Facilities" was published in the Official Gazette dated 22.09.2008 and numbered 27005 and entered into force. The Communiqué provides that the consumption of energy, water and environmentally harmful substances and the reduction of waste amount, the improvement of energy efficiency, the promotion of the use of renewable energy resources, the planning and realization of accommodation enterprises sensitive to environment from the investment stage, the harmonization of environment, awareness of environmental awareness, providing training and cooperating with relevant institutions and organizations. There are currently 403 facilities with Green Star certificate [8].

The facilities that will receive the Certificate of Ambassadorial Accommodation from the Ministry (Green Star Symbol) will contribute to the preservation of the environment, at the same time they will be able to create a privilege in promotional and marketing, without sacrificing service qualities and with saving to the economies of the facilities and country.

In the fourth section of the Official Gazette published in 14.08.2006 under the heading "Regulation on the application of energy support to cultural investments and initiatives with income tax withholding, insurance premium employer share and water price reduction", there are provisions for energy support and water price reduction. According to this, energy support, natural gas licensed for cultural investments or entrepreneurs with exclusively certified investment or 
entrepreneurship and paid in advance for invoicing period, and active electricity energy consumption rate are applied for $20 \%$ for five years. In the case of waterlevel applications, cultural investments or enterprises pay exclusively certified investment or water for the enterprise from the lowest amount applied in the region[9]. Relevant facilities need to have an Environmentally Responsible Accommodation Facility Certificate to receive these documents.

"Resource Efficiency", one of the 12 targets of sustainable tourism, aims to minimize the use of limited and non-renewable resources in the development and operation of tourism companies and services [6]. The fulfillment of this objective will be possible by the use of renewable energy sources and by the choice of energy performance enhancing technologies in the design and investment phase or after construction. The effectiveness of sustainability in tourism depends on the prioritization and use of renewable energy sources in the use of energy. The use of energy in buildings has a large share in total energy consumption and there is great responsibility for the designer architects and engineers involved in reducing this consumed energy without concession, aesthetic concerns and current living standards.

\section{ENERGY PERFORMANCE ENHANCING TECHNOLOGIES THAT CAN BE USED FOR ENERGY EFFICIENCY IN SUSTAINABLE TOURISM}

Tourism operators, especially hotels, have to serve over a certain standard 24 hours a day, 7 days a week. They consume high amounts of energy in the sense of heating, cooling, ventilation, lighting. Looking at the mass tourism in Turkey, it is observed that the facilities are mostly located in the Mediterranean and Aegean Regions, where solar radiation is located in high amounts. In this context, it can be said that solar energy is the most suitable renewable energy source in terms of providing electricity and thermal energy.

In tourism facilities, the use of technologies such as ice thermal storage, thermal energy storage with phase change materials (PCM), variable refrigerant flow air conditioning systems (VRV/VRF) and renewable energy assisted heat pumps to accommodate thermal energy will contribute to energy efficiency.

Electrical energy and heating-cooling loads are at the forefront of the energy expenditures of the hotels during the season. The use of solar energy as an alternative energy source in tourism facilities will significantly reduce the carbon emissions. Accordingly, there is a technology that will provide significant gains in electricity and thermal energy that can be used in tourism facilities; Photovoltaic Thermal (PV- T) Collector Technology is recommended. 


\section{PHOTOVOLTAIC THERMAL (PV-T) COLLECTOR TECHNOLOGY}

For solar photovoltaic (PV) systems, one of the major issues is currently only 15$20 \%$ of the solar energy incident on a PV panel can be converted to electricity, with the rest being transformed into heat, this part of thermal energy can be effectively reutilized to produce heating effect [10]. Depending on the properties of the materials produced by the panels, solar energy containing radiation in different wavelengths turns only the portion corresponding to the spectral response intervals into electricity, while a large proportion generates heat load in the photovoltaic material. This excess heat load reduces both the instantaneous efficiency of the photovoltaic panels and the deterioration of the material structure in the long run. Photovoltaic thermal (PV-T) systems are designed to remove and evaluate this excessive heat build up by solar radiation that can not be converted to electricity. With PV-T systems, both the excess heat load can be removed from the photovoltaic material and this energy can be used as heat. Thus, an energy system that produces both heat and electricity from a single mod is emerging [11].

This system was originally proposed by Kern and Russell about thirty years ago, and today it has become a widespread research topic [12]. Although most research focuses on increasing the efficiency of the PV system, the PV-T system offers an alternative solution to the solar heating effect. The operation scheme of PV-T collector technology is given in Fig 1.

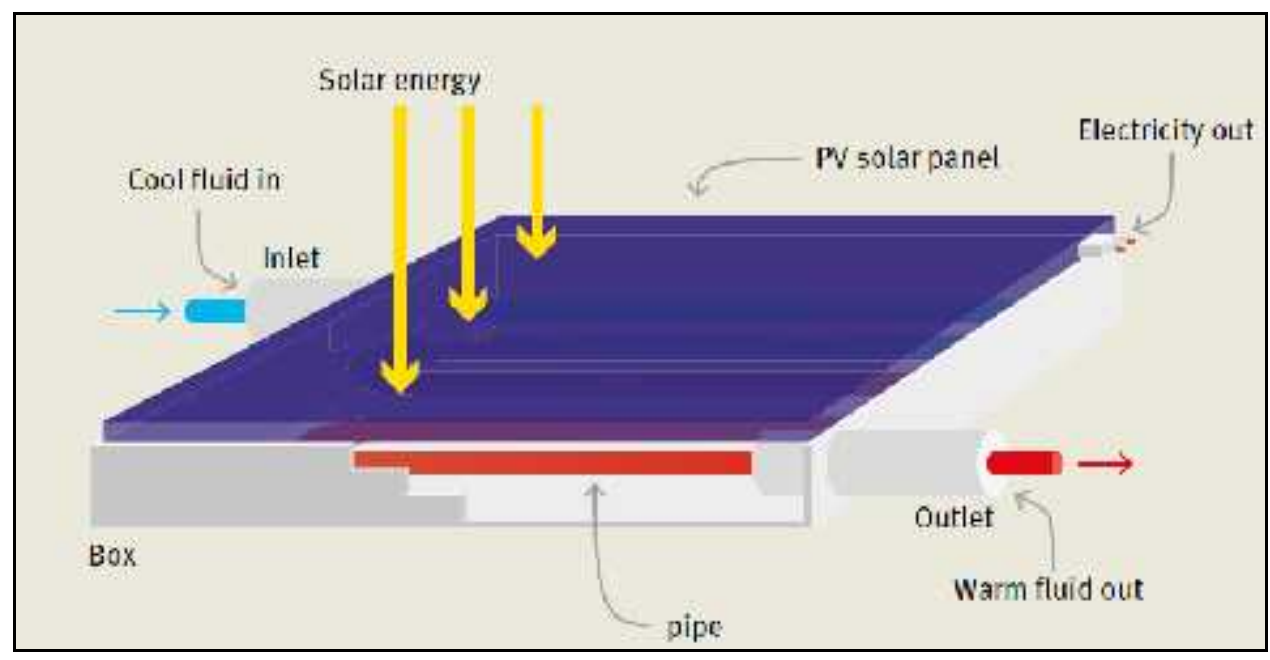

Fig. 1: Operation scheme of PV-T collector technology

Source: 12. Ramos, A., Guarracino, I., Mellor, A., Alonso-Álvarez, D., Childs, P., Ekins-Daukes, N. J., Markides, C. N., 2017. Solar-Thermal and Hybrid Photovoltaic-Thermal Systems for Renewable Heating, Imperial College London: Grantham Institute Briefing paper, 22. 


\section{PV-T TECHNOLOGY THERMODYNAMICS}

Hybrid PV-T technology, which consists of photovoltaic and photo-thermal interaction, produces both electricity and heat energy from sunlight. The advantage of PV-T collectors is that they can reduce the cost of equipment through common use, compared to PV and thermal systems being used side by side. At the same time, the panels are cooled to some extent and their efficiency remain at high levels.

\section{Energy Balance of PV-T Collector}

The energy balance of the photovoltaic-thermal collectors is given as follows.

$Q_{u, P V-T}=Q_{T}-Q_{L}$

Equation (1) can be written as [13]

$Q_{u, P V-T}=A_{c} F_{R}\left[(\tau \alpha)_{e f f} I_{S}-U_{L}\left(T_{i}-T_{a}\right)\right]$

Here, $F_{R}$ is the heat gain factor, $(\tau \alpha)_{e f f}$ is the effective permeability absorption coefficient, $U_{L}$ is the total collector heat loss coefficient $(\mathrm{W} / \mathrm{m} 2 \mathrm{~K})$, and $T_{i}$ is the inlet temperature of the working fluid. The collector heat gain factor is given by Equation (3).

$F_{R}=\frac{\dot{m} C_{p}}{A_{c} U_{L}}\left[1-\exp \left(-\frac{A_{c} U_{L} F^{\prime}}{\dot{m} C_{p}}\right)\right]$

$F^{\prime}$ is the collector efficiency factor, which can be calculated by Equation (4).

$F^{\prime}=\frac{1 / U_{L}}{W\left[\frac{1}{U_{L}[D+(W-D) F]}+\frac{1}{C_{b}}+\frac{1}{\pi D h_{f}}\right]}$

$\mathrm{W}$ is the heat transfer coefficient in the pipes (m) through which the heat transfer fluid passes, D is inner diameter (m) of the pipe, $F$ is standard winglet efficiency, $C_{b}$ boundary conductivity coefficient and $h_{f}$ is heat transfer coefficient in pipes. 


\section{Energy Efficiency of PV-T Collector}

Energy efficiency of PV-T Collector is given in Equation (5) [13].

$\eta_{P V-T}=\frac{\dot{Q}_{u, P V-T}}{I_{s} A_{c}}=\frac{F_{R}\left[(\tau \alpha)_{e f f} I_{s}-U_{L}\left(T_{i}-T_{a}\right)\right]}{I_{s}}$

The thermal performance of the PV-T collectors depends on the water inlet and ambient temperature, the intensity of the sun's rays coming on the collector, and the reflector. The daily total efficiency of PV-T collectors is shown as follows, similar to electricity and thermal efficiency.

$\eta_{P V-T, D}=\frac{\eta_{E}}{\eta_{p}}=\eta_{T, P V-T}$

Here $\eta_{p}$ is the electricity efficiency for a power plant in operation.

\section{Exergy Balance of PV-T Collector}

Heat losses in the collector cause heat gain for PV-T system. Therefore, the exergy balance of PV-T collectors is given as follows.

$$
E x_{P V-T}=E x_{P V-T, e l}+E x_{P V-T-\text { thermal }}-E x_{P V-T, d-e l}
$$

The heat generated by the PV system in the PV-T collector $\left(E x_{P V-T-\text { thermal }}\right)$ is taken as gain since it is turned into useful work. $\left(E x_{P V-T, d-e l}\right)$ is the electrical energy degradation resulting from internal losses. The electrical energy and thermal exergy of the PV-T system are given in Equation (8) and Equation (9), respectively.

$$
\begin{aligned}
& E x_{P V-T, e l}=E x_{P V-T, d-e l}=V_{m} I_{m} \\
& E x_{P V-T-\text { thermal }}=\left(1-\frac{T_{i}}{T_{a}}\right) Q_{u, P V-T}
\end{aligned}
$$

Utilizing Equation (8) and Equation (9), the following general expression can be obtained. 
$E x_{P V-T}=V_{m} I_{m}+\left(1-\frac{T_{i}}{T_{a}}\right) Q_{u, P V-T}$

\section{Exergy Efficiency of PV-T Collector}

PV-T collectors convert both electric energy and waste heat into useful work, the efficiency of exergy is given as follows.

$\psi_{P V-T}=\frac{E x_{P V-T}}{E x_{\text {sun }}}=\frac{V_{m} I_{m}+\left(1-\frac{T_{a}}{T_{i}}\right) Q_{u, P V-T}}{\left(1-\frac{T_{a}}{T_{s}}\right) A_{c} I_{s}}$

\section{APPLICATION OF PV-T TECHNOLOGY TO SAMPLE TOURISM FACILITY}

A tourism facility in the Kemer county of Antalya has been investigated in order to evaluate the energy efficiency gains of PV-T collector technology in tourism facilities. Daily global solar radiation data and daily sunshine periods are shown in Fig. 2, the energy values of the facility is shown in Tab. 1.

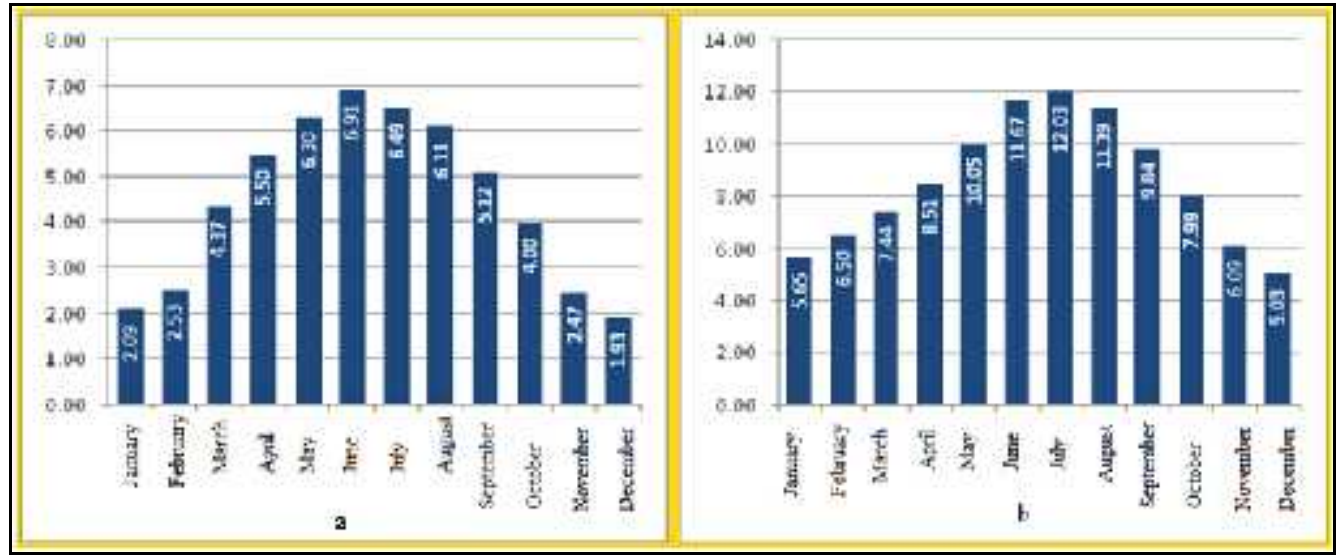

Fig. 2: a. Kemer County Global Radiation (kWh/m²-day), b. Kemer County Hours of Sunshine (hrs) Source: 14. General Directorate of Renewable Energy of Republic of Turkey, 2017. Solar Energy Potential Atlas (GEPA) [online], <http://www.eie.gov.tr/mycalculator/pages/7.aspx> [26.08.2017] 
Tab. 1: Energy values of the facility

\begin{tabular}{|c|c|}
\hline Installed power & $630 \mathrm{~kW}$ \\
\hline Monthly average energy consumption & $96840 \mathrm{kWh}$ \\
\hline Total roof area & $860 \mathrm{~m}^{2}$ \\
\hline Available roof area & $800 \mathrm{~m}^{2}$ \\
\hline Type of energy used in the facility & $\mathrm{LNG}$ \\
\hline Cooling load & $145 \mathrm{~kW}$ \\
\hline
\end{tabular}

Source: Energy values were obtained from the technical department of the tourism facility.

Although the available roof area is $800 \mathrm{~m}^{2}, 375 \mathrm{PV}-\mathrm{T}$ panels with $1.37 \mathrm{~m}^{2}$ of collecting area each were selected, so that they can not be exposed to shading effect and maximum efficiency can be obtained. The total area covered by the panels is $513.75 \mathrm{~m}^{2}$. The installed capacity of $75 \mathrm{~kW}$ PV panel will cover $12 \%$ of the electricity energy of the plant. The amount of electrical energy that can be produced according to the type of panel of the county where the tourism facility is located is shown in Fig. 3. Accordingly, the Monocrystalline Silicon cell collector, which has the highest level of utility and electricity generation potential, has been selected as the PV-T collector.

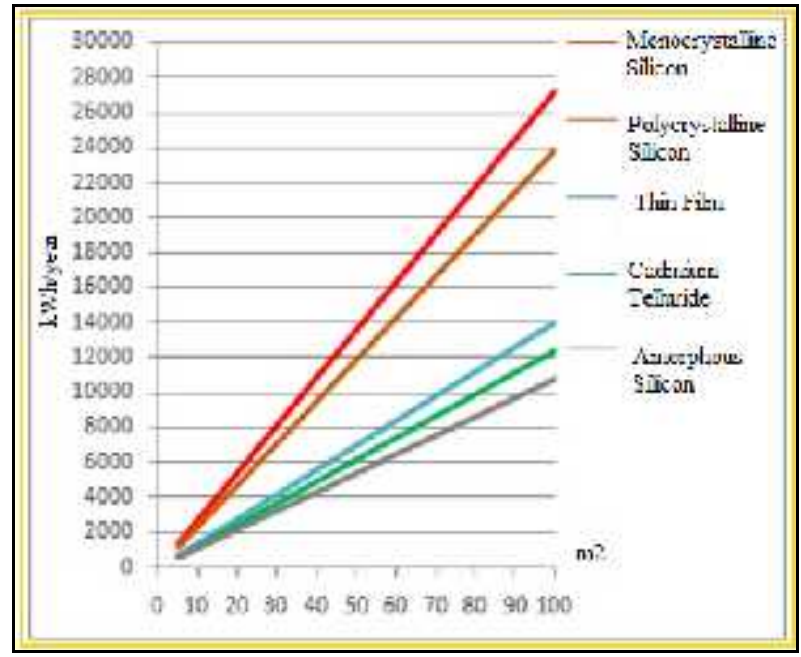

Fig. 3: Annual PV power generation potential of Kemer County (KWh-year) Source: 14. General Directorate of Renewable Energy of Republic of Turkey, 2017. Solar Energy Potential Atlas (GEPA) [online], $<$ http://www.eie.gov.tr/mycalculator/pages/7.aspx> [26.08.2017]

The cost of the PV-T system, including panels, boilers, electric cables and hot water production components, including taxes, was calculated at approximate 215,000 
USD. The electrical data and mechanical characteristics of the collectors are shown in Tab. 2 and Tab. 3, respectively.

Tab. 2: Electrical Data of PV-T Solar Panel

\begin{tabular}{|c|c|}
\hline Maximum Power $\left(\mathrm{P}_{\mathrm{max}}\right)$ & $200 \mathrm{~W}_{\mathrm{p}}$ \\
\hline Maksimum Power Voltage $\left(\mathrm{V}_{\mathrm{mpp}}\right)$ & $36.4 \mathrm{~V}$ \\
\hline Maximum Power Current $\left(\mathrm{I}_{\mathrm{mpp}}\right)$ & $5.2 \mathrm{~A}$ \\
\hline Open Circuit Voltage $\left(\mathrm{V}_{\mathrm{oc}}\right)$ & $45.2 \mathrm{~V}$ \\
\hline Short Circuit Current $\left(\mathrm{I}_{\mathrm{sc}}\right)$ & $5.6 \mathrm{~A}$ \\
\hline
\end{tabular}

Source: 15. Solimpeks Marketing \& Engineering, 2017. Hybrid PV-T Panel

Catalogue.

Tab. 3: Mechanical Characteristics of PV-T Solar Panel

\begin{tabular}{|c|c|}
\hline Cell Type & Monocrystalline Silicon \\
\hline Cell Number & 72 \\
\hline Dimensions $(\mathrm{mm})$ & $828 \times 1601 \times 90$ \\
\hline Total surface area $\left(\mathrm{m}^{2}\right)$ & 1.37 \\
\hline Weight $(\mathrm{kg})$ & 24.4 \\
\hline Front Glass & $4 \mathrm{~mm}$ PV Module Glass \\
\hline Test Pressure (bar) & 10 \\
\hline Maximum working pressure (bar) & $<110^{\circ} \mathrm{C}$ \\
\hline Maximum Heat & $2017 . \mathrm{Hy}^{\mathrm{P}} \mathrm{PV}-\mathrm{T} \mathrm{Pan}$ \\
\hline
\end{tabular}

Source: 15. Solimpeks Marketing \& Engineering, 2017. Hybrid PV-T Panel

Catalogue.

The thermal system has a capacity of producing 17 tons of hot water at a temperature at $50{ }^{\circ} \mathrm{C}$ per day. Considering the conventional system used to heat water in the plant, the electricity required to produce 17 tons of water can be calculated as follows.

$Q_{h}=m c \Delta T$

Here the $Q_{h}$ value is $789.5 \mathrm{kWh}$ and the cost to produce this heat load is 2842 USD per month.

The PV system, one of the recommended subsystems, will generate $19.12 \mathrm{kWh}$ of electricity per month and earn 2295 USD. (The cost of single-stage electric energy for commercials is 0.12 USD / $\mathrm{kWh}$.) Maximum thermal benefit was 2842 USD per month. Therefore, the monthly earnings will be calculated as 5137 USD. With the energy efficiency of the thermal subsystem, the system repays itself in approximate 
3.50 years. Together with energy efficiency, fossil fuel consumption will be avoided for hot water supply. PV-T technology seems to be quite suitable due to the sunshine period and the amount of solar radiation in the area where the plant is located.

\section{CONCLUSIONS}

Increasing the energy performance of facilities in order to meet the objectives of sustainability and renewable energy policies in the tourism sector is also an important aspect of increasing the efficiency of renewable energy systems. The benefits of increased renewable energy use and appropriate energy consumption are to reduce environmental pollution. From an economic standpoint, highly efficient sustainable systems offer significant potential to reduce investment and maintenance costs.

The fact that PV-T collectors provide electrical energy as well as thermal energy contributes to significantly reduce the systems payback period. At the same time, hot water production is a very important requirement for tourism facilities and a significant part of energy consumption. Because PV-T collectors, PV panels and solar collectors that generate hot water are integrated into each other, the space to install the system is considerably reduced. Another advantage of PV-T technology is that solar radiation, which PV panels can not turn into electricity, is converted into useful heat energy, while PV panels are cooled down to provide high energy efficiency levels.

In this study, it was found that the availability of PV-T systems in tourism facilities in areas with high solar radiation and sunshine hours is adequate. The global solar radiation values of the area in where the tourism facility is vary from 1.93 to 6.91 $\mathrm{kWh} / \mathrm{m}^{2}$ day, with an average of $4.48 \mathrm{kWh} / \mathrm{m}^{2}$ day. In addition, sunshine hours in the area where the plant is located are suitable for using solar energy. The sunshine period in the region which is investigated (Kemer County, Antalya, Turkey) ranges from 5.03 to 12.03 hours per day, with an average of 8.5 hours. The existing facility has been investigated and recommended for the installation of an energy efficient system based on renewable energy. According to this, the gain obtained from electrical and thermal energy will provide the repayment of the system that can be installed about 3.50 years. Government incentives and reductions that may be taken are not included in the calculations. The addition of these discounts and incentives will have much more economic gain.

It is known that energy systems in the world are being tried to utilize renewable technologies at the maximum level. In countries like Turkey where flat plate solar collectors are widely used but PV systems are not, PV-T collectors have the potential to be used in many areas including the tourism sector. Accordingly, solar 
assisted renewable energy systems with a good integration can be said to be quite suitable technologies for tourism facilities in Turkey.

\section{NOMENCLATURE}

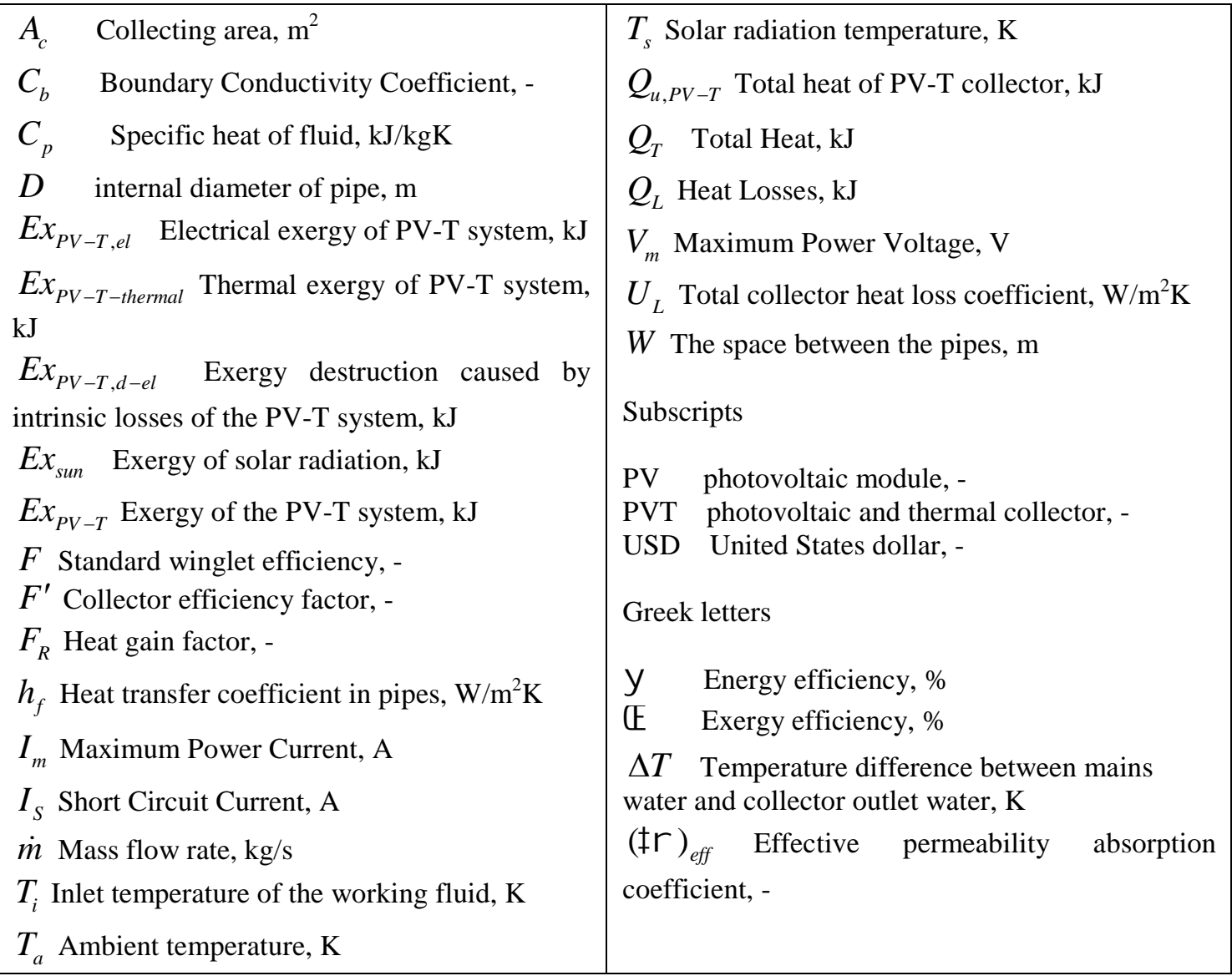

\section{REFERENCE LIST}

1. Dincer, M.Z., Aslan, O., 2008. Sustainable development, Renewable Energy Sources and Hydrogen Energy: Turkey Assessment, Istanbul, Turkey: Istanbul Chamber of Commerce Publications, 28 (in Turkish).

2. Ozturk, L., 2007. Sustainable development, Ankara: Imaj Publishing House, ISBN:978-975-8752-40-9, 107 (in Turkish).

3. Daly, H.E., 1990. Towards Some Operational Principles of Sustainable Development, Ecological Economics, 2(1), 1-6.

4. Goodland, R., 1995. The Concept of Environmental Sustainability", Annual Review of Ecology and Systematics, 1-24. 
5. Worlbank HNP Stats, 2017. World Population Prospects The 2017 Revision [online].

<https://esa.un.org/unpd/wpp/Publications/Files/WPP2017_KeyFindings.pdf > [15.10.2017].

6. United Nations Environment Programme, 2005. Making tourism more sustainable: A guide for policy makers, ISBN:92-807-2507-6 .

7. UNWTO, Tourism and Millenium Developement Goals [online]. <www.unwto.org/tourism\&mdgsezine> [07.09.2017]

8. Ministry of Culture and Tourism of the Republic of Turkey, 2017. Environmentally Sensitivity Campaign (Green Star), [online]. <http://yigm.kulturturizm.gov.tr/TR,11596/cevreye-duyarlilik-kampanyasi-yesilyildiz.html> [15.08.207], (in Turkish).

9. Official Gazette of the Republic of Turkey, No: 26228, 2006. Culture investment and enterprises with income tax withholding, share of insurance premium employer and water cost reduction and regulation on the application of energy support, [online] <http://www.resmigazete.gov.tr/eskiler/2006/07/20060714-4.htm> [25.08.2017], (in Turkish).

10. Ge, T.S., Wang, R.Z., Xu, Z.Y., Pan, Q.W., Du, S., Chen, X.M., Ma, T., Wu, X.N., Sun, X.L., Chen, J.F., 2017. Solar heating and cooling: Present and future development. Renewable Energy, 1-15.

11. Kandilli, C., Külahlı, G., Savcı, G., 2013. Photovoltaic Thermal (PVT) System 2D Thermodynamic Modeling and Comparison with Experimental Results, zmirTurkey: XI. Turkish Society of HVAC and Sanitary Engineers Congress, 1323-1335. 12. Ramos, A., Guarracino, I., Mellor, A., Alonso-Álvarez, D., Childs, P., EkinsDaukes, N. J., Markides, C. N., 2017. Solar-Thermal and Hybrid PhotovoltaicThermal Systems for Renewable Heating, Imperial College London: Grantham Institute Briefing paper, 22.

13. Ozturk, M., Ozek, N., Batur, H., Koc, M., 2011. Thermodynamic Assessment of Photovoltaic (PV) Systems and Photovoltaic-Thermal (PV-T) Collectors, Mühendis \& Makine, 619, 50-62, (in Turkish).

14. General Directorate of Renewable Energy of Republic of Turkey, 2017. Solar Energy Potential Atlas (GEPA) [online], <http://www.eie.gov.tr/mycalculator/pages/7.aspx> [26.08.2017]

15. Solimpeks Marketing \& Engineering, 2017. Hybrid PV-T Panel Catalogue. 